\title{
Rural Residents' Satisfaction of Household Latrine and its Influencing Indicators: Evidence from Sichuan, China
}

\author{
Yibin $\mathrm{Ao}^{1}$, Jiayue $\mathrm{Li}^{2 *}$, Yunfeng Chen ${ }^{3}$, Yan Wang ${ }^{4}$ \\ ${ }^{I}$ College of Environment and Civil Engineering, Chengdu University of Technology, Chengdu, Sichuan China, 610059 \\ ${ }^{2}$ Tianfu College, Southwestern University of Finance and Economics, Chengdu, Sichuan China, 610000 \\ ${ }^{3}$ School of Construction Management Technology, Purdue Polytechnic Institute, Purdue University, West Lafayette, IN 47907 \\ ${ }^{4}$ Department of Engineering Management, Sichuan College of Architectural Technology, Deyang, Sichuan China, 618000
}

\begin{abstract}
We conducted a second survey of household latrine based on the first survey study findings of rural facilities that toilet is the most significant influencing factor affecting farmers' satisfaction. The popularity proportion of rural sanitary latrines in China has been low, and the health of rural residents and the environmental sanitation in rural areas have not been effectively guaranteed. Factor analysis and logistic regression models are used to study the current situation of rural household latrines, rural residents' satisfaction and its influencing indicators of Sichuan. This research led to three key findings: 1) the present situation of rural household latrine construction in Sichuan is not ideal; 2) rural residents are relatively satisfied with rural household latrines; 3) rural residents' satisfaction is affected mainly by basic situation of latrines, village committee performance, recovery time, whether the latrine construction is worthy, transparency of village affairs, sources and subsidies of funds, construction participants and construction methods. Results of this study lay a foundation for further research about rural household latrines, and provide a theoretical basis for the construction and reform of rural household latrines in Sichuan.
\end{abstract}

Keywords: household latrine, rural area, environmental sanitation, residents' satisfaction, investigation

\section{Introduction}

Latrines are an essential part of every family. A latrine in good hygienic condition and complete facilities plays an important role in improving rural residents' quality of life and rural sanitation environment, and ensures the health of rural residents. According to "Hygienic specification for rural household latrine" (Hygienic specification for rural household latrine (GB19379-2012)), a sanitary latrine should meet the following basic conditions: having walls, roof, no leakage tanks, and air-tight lid, cleanliness, no maggots, odorless, removing feces regularly, and having innocent treatment. Innocuous-sanitary latrines have facilities that could reduce the infectivity of biological pathogenic factors in feces. Innocuous-sanitary latrines include three septic latrines, double urn funnel latrine, three unicom biogas pool latrine, sanitary latrine, double pit latrine and water flushing latrine with complete sewer system and sewage treatment facilities.

Prior to this study, we conducted a survey on rural facilities and found that the construction of rural latrines has a great influence on rural residents' satisfaction among several rural infrastructures (Ao et al 2017). Based on the previous study, a questionnaire was conducted to study the current construction status and rural residents' attitudes toward their household latrines in Sichuan. We selected evaluation indexes to create a comprehensive questionnaire that consists of individual characteristics of interviewees, characteristics of villages, household latrine building conditions, cost of household latrines, household latrine use condition, and attitudes of rural residents. The reliability of the questionnaire was analyzed to test the validity of the survey. Factor analysis was then conducted to identify 13 factors. Finally, logistic regression model was used to analyze the 13 factors to test their effects on rural residents' satisfaction.

Sichuan province is located in the hinterland of Southwest China, and its area is $484,144 \mathrm{~km}^{2}$, with a population of $82,620,000$ and the number of rural residents is $41,960,000$. Statistics show that in the first three quarters of 2017, Sichuan's gross domestic product (GDP) reached CNY 27,297 billion, with an increase of $8.1 \%$ compared to the same period of last year, and its growth rate is $1.2 \%$ higher than the national average level. In the first three quarters, the total investment in fixed assets in Sichuan province was CNY 24,366 billion, with an increase of $10.3 \%$ over the previous year, and the investment of the first industry (Agriculture) was CNY 1,036 billion, with an increase of $22.6 \%$ compared to the same period of last year (Sichuan Statistics Yearbook (2017)).

\footnotetext{
* Corresponding Author: Jiayue Li, 13688176916@163.com
}

Received August 29, 2018; Revised September 29, 2018; Accepted October 10, 2018; Available online October 30, 2018 


\section{Literature Review}

In recent years, many studies related to rural latrines have been done in China, and they can be divided into several aspects, such as the situation, effect, and benefits of rural latrine reform along with existing problems in the process of rural latrine reform.

Research about the situation of rural latrine reform could be divided into theoretical analysis and empirical study. $\mathrm{Wu}$ (2003) proposed that there were problems as low enthusiasm and low participation of rural residents, insufficient attention of leaders and lack of policy support in the reform of rural latrines in Taizhou in 2003 and put forward corresponding suggestions. Hang (2008) argued that rural latrine reform in China have problems such as the masses' lacking enough understanding, unstandardized construction operations, lack of technical guidance and funding problems. Zhang et al (2008) analyzed reasons for the obstruction of rural latrine reform from the perspective of cultural distance. Hou and Wang (2011) studied problems in the reform of rural latrine from the perspective of rural civilization and put forward corresponding suggestions. Ye and An (2013) analysed existing researches related to rural latrine reform and proposed that rural latrine reform is helpful for the prevention of intestinal infection, the improvement of rural environmental sanitation and the improvement of rural residents' health awareness.

In an empirical analysis, Pan et al (1995) carried out a background investigation, which was the first national survey to study rural latrines and excreta disposal in China in 1993. The survey results showed that China's rural latrine proportion sanitary latrine popularity proportion were $85.9 \%$ and $7.5 \%$ respectively, and the fecal harmless treatment proportion was $13.5 \%$ in 1993. Zhang et al (2000) adopted a stratified cluster method to investigate the prevalence of rural sanitary latrines in Shandong province at the end of 1999. He pointed out that there were some problems such as low starting points and low construction levels in rural latrines in Shandong. The reform situation of rural latrines in Cangxi and Mabian were investigated by Tang et al (2003) in 2001, the results showed that the proportion of privy in rural household latrines reached $86.17 \%$ in Cangxi and Mabian. Niu and $\mathrm{Zu}$ (2004) pointed out that the whole level of rural latrine reform of family in Anhui was not ideal in 2002, and the economy had a significant impact on latrine reform behavior. Zhang et al (2005a, 2013) pointed out that the proportion of popularization of sanitary latrines was $33.46 \%$, and the proportion of decontamination of feces was $10.34 \%$ in 2003 . They reinvestigated the situation of rural latrine reform of Sichuan in 2011, and the results showed that the proportion of innocuous-sanitary latrine was $48.75 \%$, which has got great improvement compared with the proportion of 2003. Jin et al (2007) investigated the situation of rural latrine reform during 2004-2005, and the results showed that the proportion of popularization of sanitary latrine and the proportion of decontamination of feces were lower than the national average level. Fu et al (2006) investigated the situation of rural latrine construction of 5 counties in Xianyang in 2004, and they put forward a suitable sanitary latrine type for Xiangyang and pointed out that the proportion of popularization of sanitary latrine and the proportion of decontamination of feces were both low, while villagers lacking hygienic knowledge and enthusiasm. Lin et al (2008) and Zhan et al (2011) studied rural latrine reform results during 2005-2009 of Fujian through questionnaires, field observations, and interviews, then analyzed the correlation between rural latrine reform and economy. Investigation results of Yao et al (2009) showed that the prevalence proportion of rural sanitary latrines in China was $23.83 \%$ in 2006, while the prevalence proportion of sanitary latrines in the eastern region was obviously higher than that in other areas. They also pointed out that the construction of sanitary latrine was positively related to economy. Besides, Guo et al (2008), Zhang (2012), and Liu et al (2016) have also respectively studied the situation and effect of rural latrine reform of Liaocheng, Tianjin, and Shijiazhuang. They also have investigated the popularization of sanitary latrines and analyzed problems and experience in their work.

On the basis of researches related to the situation of rural latrine, Liang et al (2002), Fu et al (2004), and Li et al (2013) studied the effect of rural latrine reform. Liang et al (2002) studied the influence on environmental sanitation brought by latrine reform in Tongbai through the comparison between villages without latrine reform and villages with latrine reform. And they pointed out that the reform of rural latrines could improve the sedimentation proportion of parasitic eggs, reduce the flies and reduce the pollution on soil and water resources. Fu et al (2004) surveyed the rural latrine status before and after the implementation of the World Bank lending project for rural water supply and sanitation. According to the survey, the sanitary conditions of rural latrines have been significantly improved, and proportion of construction and use of sanitary latrines have also increased significantly through the development of the project. Li et al (2013) proposed that the percent of qualified fecal decontamination was only $45.2 \%$, and the effect of fecal decontamination was significantly influenced by latrine construction quality, condition of fecal exposure, and rural residents' awareness of excreta disposal knowledge.

Researches on the benefits of rural latrine reform are mainly focused on environmental benefits, hygienic benefits, economic benefits and social benefits. Wen et al (2005) analyzed economic benefits and social benefits brought by the reform of latrines in rural areas of Hunan. Zhang et al (2005b) analyzed the change of rural residents' hygienic consciousness and behavior through a contrast between reformed villages and villages without reform. Yang et al. (2005) argued that rural latrines reform could bring hygienic benefits, economic benefits, environmental benefits and social benefits. They also put forward suggestions such as leadership attention, publicity and education, long-term management from the rural latrines reform condition in 2005.

As to international, much attention has also been paid to the construction of rural regional toilets in underdeveloped areas. Gedefaw et al (2015) studied the latrine utilization and associated factors among rural communities of Northwest Ethiopia and concluded that a construction with proper household-based health education, good construction, and 
supportive supervision would help on the sustainment of rural toilet. Hussain et al (2017) did a qualitative study in rural Bangladesh to study advantages and limitations for users of double pit pour-flush latrines. They pointed out that the double pit pour-flush latrine model is feasible to use and maintain, and the double pit pour-flush latrine increased accessibility of a sanitation facility for low-income residents and provided them privacy, convenience and comfort. In addition to the study of the advantages and disadvantages of rural sanitary toilets and traditional toilets, researchers also examined the relationship between rural toilets and health. Hiscox et al (2016) conducted an analysis of the health problems caused by mosquitoes in the Laos latrine, and suggested that the seal of septic tanks should be kept through the covering layer to prevent mosquitoes from entering. They point out that this simple intervention will have a global impact on the prevention of mosquito bites and the spread of diseases. Beukes et al (2017) verified existence of MDR Escherichia coli in pit latrines. They argued the presence of MDR E. coli strains in pit latrine samples demonstrated that pit latrines were potential sources for MDR bacteria. Kumwenda et al (2017) did an analysis for the differences in the prevalence of parasites from the use of an ecological toilet and a traditional pit type toilet in Malawi. They found that Ascaris lumbricoides was significantly higher in households using EcoSan latrines. They advocate EcoSan users to pay attention to safe ways of handling faecal sludge in order to reduce chances of reinfection from Ascaris lumbricoides. Yishay et al (2017) found that microfinance could greatly promote the willingness of residents to improve their toilets through a randomized-controlled trial of the rural Cambodia. The influence of the toilet on the water quality has attracted the attention of people as researches continue. Back et al (2018) appraised the groundwater risk caused by pit toilet policies in developing countries. Ferrante et al (2018) pointed out that the quality of the water supply was closely related to the distance from the toilet and stressed the importance of maintaining a sufficient distance between the access of drinking water and toilets.

In developed countries, relativlley less researches have been focused on rural infrastructure. External researches are more about wastewater treatment and environmental sanitation. Such as, Anagnostopoulos and Vavatsikos (2012) used spatial fuzzy analytic hierarchy process to help with the site selection of wastewater treatment system. Glick et al (2013) combined LCC, LCA, and economic input-output to assess the sustainability of sewage treatment project. Zhou and Liu (2015) studied infrastructure projects from the perspective of micro engineering, with the aim of creating a basic model to analyze sustainable construction and operation of infrastructure projects, and a sewage treatment plant is used as a case study.

Integrated existing researches, the reform of rural latrine in China mainly involves such problems as rural residents' lack of awareness, rural residents' low participation, insufficient capital input, lag in technology, inadequate government attention and lack of incentive mechanism, and corresponding suggestions such as creasing investment, strengthening propaganda, strengthening technical training and formulating incentive mechanism were put forward. What is worth thinking about is even if there are so many researches related to rural latrines, and problems and suggestions were proposed again and again, problems raised still have not been solved effectively.

\section{Method and Data Sources}

\subsection{Method}

In this paper, descriptive analysis, factor analysis and logistic regression model were used to analyze the satisfaction of rural residents and its influencing factors.

\subsubsection{Factor Analysis}

Factor analysis is a multivariate statistical analysis method that can convert measured variables to a small number of non-related comprehensive factors. These comprehensive factors reflect the main information of original measured variables and explain the relationship between measured variables (Tang et al 2010). Specifically, factor analysis studies the condensation of a large number of measured variables to a few factors with the least information loss ( $\mathrm{Li}$ 2008). In this paper, for as many as 44 indicators, the use of factor analysis to convert indicators into comprehensive factors is necessary. The general form of factor analysis model is:

$$
\begin{aligned}
& \mathrm{X}_{\mathrm{i}}=\mu+\mathrm{a}_{\mathrm{i} 1} \mathrm{~F}_{\mathrm{i} 1}+\mathrm{a}_{\mathrm{i} 2} \mathrm{~F}_{\mathrm{i} 2}+\cdots+\mathrm{a}_{\mathrm{in}} \mathrm{F}_{\mathrm{in}}+\varepsilon_{\mathrm{i}} \quad(\mathrm{i}= \\
& 1,2, \ldots, \mathrm{p})
\end{aligned}
$$

Among them, $X_{i}$ is a random observed variable; $F_{i}$ is a common factor; $a_{i j}(i=1,2, \ldots, p)$ is factor load; $\varepsilon_{\mathrm{i}}$ is special factor part not included in common factors.

\subsubsection{Logistic Regression Model}

The dependent variable is the rural residents' overall satisfaction of rural latrines, which is divided into two categories: "satisfied" and "dissatisfied". Statistical methods that can be used to handle categorical dependent variables include discriminant analysis, probit analysis, logistic regression model and log-linear model. Logistic regression model is an ideal model for analyzing individual decision behavior and is widely used in the analysis of influencing factors. Logistic regression model is divided into binary logistic regression analysis, which the dependent variables can only be 1 or 0 , and multinomial logistic regression analysis where the dependent variables can take more than two values (Peng 2012). In this paper, the dependent variable is divided into two categories, so the binary logistic regression model is adopted. Logistic model can be used to handle both continuous and categorical variables unlike in multiple regression analysis, where the variables must be numeric. Also, the variables are not required to meet normal distribution (Olchmaher and Davis 2003). The probability of occurrence for specimen is $P\left(y=1 \mid x_{i}\right)=p_{i}$, and two probability incidents, occurrence and non-occurrence are recorded as the following two formulas:

$$
\mathrm{p}_{\mathrm{i}}=\frac{1}{1+\mathrm{e}^{-\left(\alpha+\sum_{\mathrm{i}=1}^{\mathrm{m}} \beta_{\mathrm{i}} \mathrm{x}_{\mathrm{i}}\right)}}=\frac{\mathrm{e}^{\alpha+\sum_{\mathrm{i}=1}^{\mathrm{m}} \beta_{\mathrm{i}} \mathrm{x}_{\mathrm{i}}}}{1+\mathrm{e}^{\alpha+\sum_{\mathrm{i}=1}^{\mathrm{m}} \beta_{\mathrm{i}} \mathrm{x}_{\mathrm{i}}}}
$$




$$
1-p_{i}=1-\frac{e^{\alpha+\sum_{i=1}^{m} \beta_{i} x_{i}}}{1+e^{\alpha+\sum_{i=1}^{m} \beta_{i} x_{i}}}=\frac{1}{1+e^{\alpha+\sum_{i=1}^{m} \beta_{i} x_{i}}}
$$

where, $p_{i}$ represents the probability of occurrence of events in observation; $1-\mathrm{p}_{\mathrm{i}}$ represents the probability of nonoccurrence of events in observation; both are nonlinear functions formed only by variable $\mathrm{x}_{\mathrm{i}}$.

$\mathrm{p}_{\mathrm{i}} /\left(1-\mathrm{p}_{\mathrm{i}}\right)$ represents the ratio of the probability occurrence and the nonoccurrence of the event, named occurrence ratio. The logarithmic transformation to the occurrence ratio produces the linear model of the logistic regression model.

$$
\ln \left(\frac{p_{i}}{1-p_{i}}\right)=\alpha+\sum_{i=1}^{m} \beta_{i} x_{i}
$$

\subsection{Data Sources}

This paper is based on the Natural Science Foundation of
Sichuan Education Department Fund Project "Research on System Optimization of Agricultural Production Infrastructure Construction", and data were obtained under the organization of home research with the help of students from the Engineering Management Department of Chengdu University of Technology. To ensure the validity and authenticity of the data and to guarantee that interviewees well understand the questions, the research group used students from rural areas for a pre-interview test. A meeting was held to investigate students' opinions of rural infrastructure and guarantee the validity of questionnaires finished by students. A total of 300 questionnaires were issued, of which 153 questionnaires received were valid, with an effective rate of $51 \%$. The questionnaires were answered by 69 women and 84 men, accounting for $45.1 \%$ and $54.9 \%$, respectively. The basic situation of all investigated objects is shown in Table 1.

\begin{tabular}{|c|c|c|c|c|c|}
\hline & Index & Percentage & & Index & Percentage \\
\hline \multirow{6}{*}{ Age } & Less than 20 years & $14.0 \%$ & \multirow{2}{*}{ Gender } & Female & $45.1 \%$ \\
\hline & From 20 to 30 years & $49.0 \%$ & & Male & $54.9 \%$ \\
\hline & From 30 to 40 years & $19.6 \%$ & \multirow{6}{*}{$\begin{array}{l}\text { Family } \\
\text { member's } \\
\text { highest } \\
\text { education } \\
\text { level }\end{array}$} & Primary school & $3.30 \%$ \\
\hline & From 40 to 50 years & $11.1 \%$ & & Junior high school & $17.7 \%$ \\
\hline & From50 to 60 years & $4.60 \%$ & & High school & $12.5 \%$ \\
\hline & Over 60 years & $1.30 \%$ & & Bachelor & $62.5 \%$ \\
\hline \multirow{4}{*}{$\begin{array}{l}\text { Annual } \\
\text { gross } \\
\text { income }\end{array}$} & Less than CNY 50,000 & $52.9 \%$ & & Master & $3.30 \%$ \\
\hline & CNY 50,000 to 100,000 & $30.7 \%$ & & Doctor & $0.70 \%$ \\
\hline & CNY 100,000 to 200,000 & $14.4 \%$ & & & \\
\hline & Over CNY 200,000 & $2.00 \%$ & & & \\
\hline
\end{tabular}

Table 1. Basic information of interviewees

\section{Empirical Study}

\subsection{Index Selection and Variable Definition}

\subsubsection{Index Selection}

On the basis of existing research, we selected evaluation indices related to several aspects, such as interviewees' individual characteristics indices, village type, construction conditions of rural latrine, cost of rural latrine, conditions of use and rural residents' attitudes. Finally, 44 indices were selected. Details of evaluation indexes are shown in Table 2.

Individual characteristic indexes of rural residents, such as Gender, age, family members' highest education level and family annual income, are important parts of the questionnaire survey, which could help us to understand the individual differences, economic conditions of rural households, and views and needs of rural residents in Sichuan. Village type and village housing distribution are village characteristic indexes, which show construction and planning differences in rural household toilets among villages with different characteristics. Basic condition and construction condition indexes, such as whether there is a household latrine, latrine location, latrine type, latrine use time, latrine area, whether the household latrine has walls, a roof, and a door, ventilation in the household latrine, whether the household latrine is $10 \mathrm{~cm}$ higher than terrace, are necessary information for this investigation as they are good indicators of basic and construction conditions of household latrines in rural area.

Indexes such as whether there are a closet, a decontamination of feces, a sanitary fixture, and a fly prevention facility, sanitary condition of household latrine, frequency of feces cleaning, whether the tank is airtight without leakage, odor concentration in household latrine, whether the household latrine is reformed, frequency of failure affecting use and failure recovery time could reflect the health allocation, sanitary condition and the use of rural latrines.

Indexes related to building/renovation pattern and founding, such as cost of household latrine, household latrine building/renovation patterns, household latrine building/ renovation participants, funding sources of household latrine building/renovation, payment time of subsidy funds and 
installment, reflecting the role of the government in rural latrines construction.

Indexes related to village affairs, village planning and publicity of latrines, such as transparency of village affairs and whether there are any publicity and training in the construction, renovation, use and management of rural latrine in the village or not, indicating the role of village government in rural latrine construction.

Indexes related to feelings, attitudes and thoughts of rural residents, such as financial burden caused by household latrine construction, influence on surrounding sanitation of household latrine and satisfaction with the overall status of the household latrine, are directly related to rural residents' attitudes and ideas, and also reflect their cognition of rural household latrine.

Table 2. Variables Definition

\subsubsection{Variable Definition}

The Likert scale was used for the questionnaire analysis. As the number of options in this study involves several indexes and number of options among these indexes are quite different, so variable definition of indexes, option number of which is not 5 , is defined by linear insertion, to ensure parameters of all variables are controlled between 1-9 so that we could compare the results of different indicators more intuitively. Meanwhile, parameters, which have a degree of good and bad, are arranged in order from bad to good. As "Satisfaction with the overall status of the household latrinew is only used in logistic regression analysis, so the variable definition is: $0=$ dissatisfied, $1=$ satisfied. Variables are shown in Table 2.

\begin{tabular}{|c|c|}
\hline Index & Variable definition \\
\hline Village type $\left(\mathrm{X}_{1}\right)$ & $\begin{array}{l}1=\text { ordinary village, } 3.67=\text { township resident, } 6.33=\text { combination of } \\
\text { urban and rural areas, } 9=\text { both township resident and a combination of } \\
\text { urban and rural areas }\end{array}$ \\
\hline Gender $\left(\mathrm{X}_{2}\right)$ & $1=$ Female, $9=$ Male \\
\hline Age $\left(\mathrm{X}_{3}\right)$ & $\begin{array}{l}1=\text { over } 60 \text { years, } 2.6=\text { from } 50 \text { to } 60 \text { years, } 4.2=\text { from } 40 \text { to } 50 \text { years, } 5.8 \\
=\text { from } 30 \text { to } 40 \text { years, } 7.4=\text { from } 20 \text { to } 30 \text { years, } 9=\text { less than } 20 \text { years }\end{array}$ \\
\hline Family members'highest education $\left(\mathrm{X}_{4}\right)$ & $\begin{array}{l}1=\text { primary school, } 2.6=\text { junior high school, } 4.2=\text { high school, } 5.8= \\
\text { Bachelor, } 7.4=\text { Master, } 9=\text { Doctor }\end{array}$ \\
\hline Annual family income $\left(\mathrm{X}_{5}\right)$ & $\begin{array}{l}1=\text { less than CNY50,000, } 3.67=\text { from CNY50,000 to } 100,000,6.33= \\
\text { CNY } 100,000-200,000,9=\text { over CNY200,000 }\end{array}$ \\
\hline Village housing distribution $\left(\mathrm{X}_{6}\right)$ & $\begin{array}{l}1=\text { very decentralized, } 3=\text { decentralized, } 5=\text { moderate, } 7=\text { centralized, } 9 \\
=\text { very centralized }\end{array}$ \\
\hline Whether there is a household latrine $\left(\mathrm{X}_{7}\right)$ & $1=$ no, $9=$ yes \\
\hline Household latrine location $\left(\mathrm{X}_{8}\right)$ & $1=$ outside the yard, $5=$ in the yard, $9=$ indoor \\
\hline Household latrine type $\left(\mathrm{X}_{9}\right)$ & $\begin{array}{l}1=\text { others, } 2=\text { pit type, } 3=\text { loop type, } 4=\text { fecaluria diversity, } 5=\text { triplex } \\
\text { methane tank, } 6=\text { double urn funnel, } 7=\text { three compartment septic tank, } 8 \\
=\text { double pit alternation, } 9=\text { water jet }\end{array}$ \\
\hline Household latrine use time $\left(\mathrm{X}_{10}\right)$ & $\begin{array}{l}1=10 \text { years or more, } 3.67=5-10 \text { years, } 6.33=2-5 \text { years, } 9=2 \text { years or } \\
\text { less }\end{array}$ \\
\hline Household latrine area $\left(\mathrm{X}_{11}\right)$ & $\begin{array}{l}1=\text { smaller than } 1.2 \mathrm{~m}^{2}, 2.6=1.2-1.4 \mathrm{~m}^{2}, 4.2=1.4-2.25 \mathrm{~m}^{2}, 5.8=2.25-5 \\
\mathrm{~m}^{2}, 7.4=5-10 \mathrm{~m}^{2}, 9=\text { lager than } 10 \mathrm{~m}^{2}\end{array}$ \\
\hline The household latrine has walls or not $\left(\mathrm{X}_{12}\right)$ & $1=$ no, $9=$ yes \\
\hline The household latrine has a roof or not $\left(X_{13}\right)$ & $1=$ no, $9=$ yes \\
\hline The household latrine has a door or not $\left(\mathrm{X}_{14}\right)$ & $1=$ no, $9=$ yes \\
\hline Ventilation in the household latrine $\left(\mathrm{X}_{15}\right)$ & $1=$ no ventilation, $5=$ natural ventilation, $9=$ mechanical ventilation \\
\hline $\begin{array}{l}\text { Whether the household latrine is } 10 \mathrm{~cm} \text { higher } \\
\text { than terrace }\left(\mathrm{X}_{16}\right)\end{array}$ & $1=$ no, $9=$ yes \\
\hline There is a closet or not $\left(\mathrm{X}_{17}\right)$ & $1=$ no, $9=$ yes \\
\hline $\begin{array}{l}\text { There is a decontamination of feces or not } \\
\left(\mathrm{X}_{18}\right)\end{array}$ & $1=$ no, $9=$ yes \\
\hline
\end{tabular}




\begin{tabular}{|c|c|}
\hline There are sanitary fixture or not $\left(\mathrm{X}_{19}\right)$ & $1=$ no, $5=$ having a part, $9=$ all have \\
\hline There is a fly prevention facility or not $\left(\mathrm{X}_{20}\right)$ & $1=$ no, $9=$ yes \\
\hline Sanitary condition of household latrine $\left(\mathrm{X}_{21}\right)$ & $1=$ bad, $5=$ moderate, $9=\operatorname{good}$ \\
\hline Frequency of feces cleaning $\left(\mathrm{X}_{22}\right)$ & $\begin{array}{l}1=\text { over } 2 \text { years, } 3.67=1-2 \text { years, } 6.33=6 \text { months to a year, } 9=\text { within } 6 \\
\text { months }\end{array}$ \\
\hline $\begin{array}{l}\text { Whether the tank is airtight without leakage } \\
\left(\mathrm{X}_{23}\right)\end{array}$ & $1=$ no, $9=$ yes \\
\hline Odor concentration in household latrine $\left(\mathrm{X}_{24}\right)$ & $1=$ obvious odor, $5=$ a little odor, $9=$ basically tasteless \\
\hline The household latrine is reformed or not $\left(\mathrm{X}_{25}\right)$ & $1=$ no, $9=$ yes \\
\hline Cost of household latrine $\left(\mathrm{X}_{26}\right)$ & $\begin{array}{l}1=\text { under CNY500, } 3.67=\text { CNY500-1000, } 6.33=\text { CNY1000-2000, } 9= \\
\text { over CNY2000 }\end{array}$ \\
\hline Household latrine renovation reason $\left(\mathrm{X}_{27}\right)$ & $\begin{array}{l}1=\text { no renovation, } 3.67=\text { people around have reformed their latrines, } 6.33 \\
=\text { under government advocacy, } 9=\text { not satisfied with the previous situation }\end{array}$ \\
\hline $\begin{array}{l}\text { Households latrine building / renovation } \\
\text { pattern }\left(\mathrm{X}_{28}\right)\end{array}$ & $\begin{array}{l}1=\text { villagers are responsible, } 3.67=\text { government advocacy organizations, } \\
\text { villagers funded, } 6.33=\text { government guidance, and provide some funds, } 9 \\
=\text { government responsible for the construction, and provide subsidies }\end{array}$ \\
\hline $\begin{array}{l}\text { Household latrine building / renovation } \\
\text { participants }\left(\mathrm{X}_{29}\right)\end{array}$ & $\begin{array}{l}1=\text { rural residents, } 2.33=\text { government, } 3.67=\text { professional construction } \\
\text { company; } 5=\text { rural residents and government, } 6.33=\text { rural residents and } \\
\text { professional construction company, } 7.67=\text { government and professional } \\
\text { construction company, } 9=\text { rural residents, government and professional } \\
\text { construction company }\end{array}$ \\
\hline $\begin{array}{l}\text { Management and maintenance participants of } \\
\text { household latrine }\left(\mathrm{X}_{30}\right)\end{array}$ & $\begin{array}{l}1=\text { no management or maintenance, } 2.14=\text { rural residents, } 3.29= \\
\text { government, } 4.43=\text { professional management company, } 5.57=\text { rural } \\
\text { residents and government, } 6.71=\text { rural residents and professional } \\
\text { management company, } 7.86=\text { government and professional management } \\
\text { company, } 9=\text { rural residents, government and professional management } \\
\text { company }\end{array}$ \\
\hline $\begin{array}{l}\text { Funding sources of household latrine building } \\
\text { / renovation }\left(\mathrm{X}_{31}\right)\end{array}$ & $\begin{array}{l}1=\text { rural residents, } 2.33=\text { government, } 3.67=\text { social capital, } 5=\text { rural } \\
\text { residents and government, } 6.33=\text { rural residents and social capital, } 7.67= \\
\text { government and social capital, } 9=\text { rural residents, government and social } \\
\text { capital }\end{array}$ \\
\hline Payment time of subsidy fund $\left(\mathrm{X}_{32}\right)$ & $\begin{array}{l}1=\text { no subsidy, } 3=6 \text { months later after the construction, } 5=3-6 \text { months } \\
\text { later after the construction, } 7=\text { within } 3 \text { months, } 9=\text { before the } \\
\text { construction }\end{array}$ \\
\hline Subsidy percentage $\left(\mathrm{X}_{33}\right)$ & $\begin{array}{l}1=\text { no subsidy, } 3=\text { under } 20 \%, 5=20 \%-50 \%, 7=50 \%-80 \%, 9=\text { more } \\
\text { than } 80 \%\end{array}$ \\
\hline $\begin{array}{l}\text { Financial burden caused by household latrine } \\
\text { construction }\left(\mathrm{X}_{34}\right)\end{array}$ & $1=$ heavy, $5=$ moderate, $9=$ basically no burden \\
\hline Frequency of failure affecting use $\left(\mathrm{X}_{35}\right)$ & $\begin{array}{l}1=\text { under } 3 \text { months, } 3.67=3-6 \text { months, } 6.33=6-12 \text { months, } 9=\text { over } 12 \\
\text { months }\end{array}$ \\
\hline Repair approach $\left(\mathrm{X}_{36}\right)$ & $\begin{array}{l}1=\text { rural residents, } 5=\text { there is a special person in the village for } \\
\text { maintenance, } 9=\text { looking for professional maintenance personnel }\end{array}$ \\
\hline Failure recovery time $\left(\mathrm{X}_{37}\right)$ & $1=$ over $36 \mathrm{~h}, 3.67=24-36 \mathrm{~h}, 6.33=12-24 \mathrm{~h}, 9=$ within $12 \mathrm{~h}$ \\
\hline $\begin{array}{l}\text { Whether the construction / renovation of the } \\
\text { household latrine is worth }\left(\mathrm{X}_{38}\right)\end{array}$ & $1=$ no, $9=$ yes \\
\hline Transparency of village affairs $\left(\mathrm{X}_{39}\right)$ & $\begin{array}{l}1=\text { opaque, villagers do not know many cases, } 5=\text { moderate, inform part } \\
\text { of the work arrangements and information, } 9=\text { transparent, inform related } \\
\text { arrangements and information }\end{array}$ \\
\hline
\end{tabular}


Availability of publicity and training are available in the construction, renovation, use and management of rural latrine in the village $1=$ no, $9=$ yes $\left(\mathrm{X}_{40}\right)$

Whether the village have a unified plan for the
household latrine $\left(\mathrm{X}_{41}\right)$
Influence on surrounding sanitation of
household latrine $\left(\mathrm{X}_{42}\right)$

$1=$ no, $9=$ yes

Influence on health of family and villagers of household latrine $\left(\mathrm{X}_{43}\right)$

$1=$ no influence, $5=$ have some influence, $9=$ significant influence

Satisfaction with the overall status of the household latrine $\left(\mathrm{X}_{44}\right)$

$1=$ no influence, $5=$ have some influence, $9=$ significant influence

\subsection{Descriptive Analysis of Rural Household Latrine}

From the survey, 79 household latrines are located indoor, 50 household latrines are in yard, and 24 household latrines are outside the yard, and the percentage points are $51.6 \%$, $32.7 \%$ and $15.7 \%$ respectively. There are 32 pit latrines for (20.9\%), 14 loop type latrines (9.2\%), 6 fecaluria diversity latrines $(3.9 \%), 10$ triplex methane tank latrines, $(6.5 \%), 3$ double urn funnel latrines (2.0\%), 6 three compartment septic tank latrines (3.9\%), 15 double pit alternation latrines
(9.8\%), and 64 water jet latrines $(41.8 \%)$. However, the percentage of decontamination of feces is only $39.2 \%$, which shows that there are still a large number of water flushing latrines which do not meet requirements of innocuoussanitary latrine. Distribution of rural household toilets type is shown in Figure 1. In order to get a better understanding of the situation in China's rural toilets, a few photos collected during the investigation are attached in Figure 2 (the first two are water jet and the third is pit type).

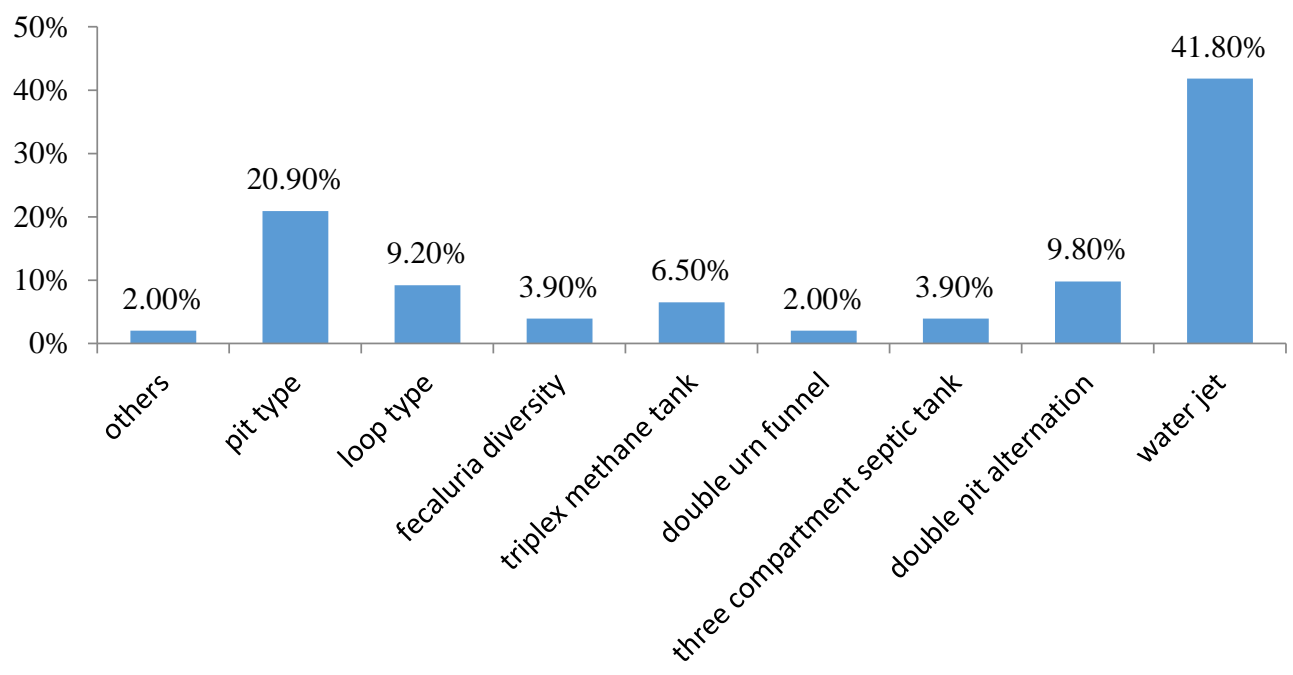

Figure 1. Distribution of rural household toilets type
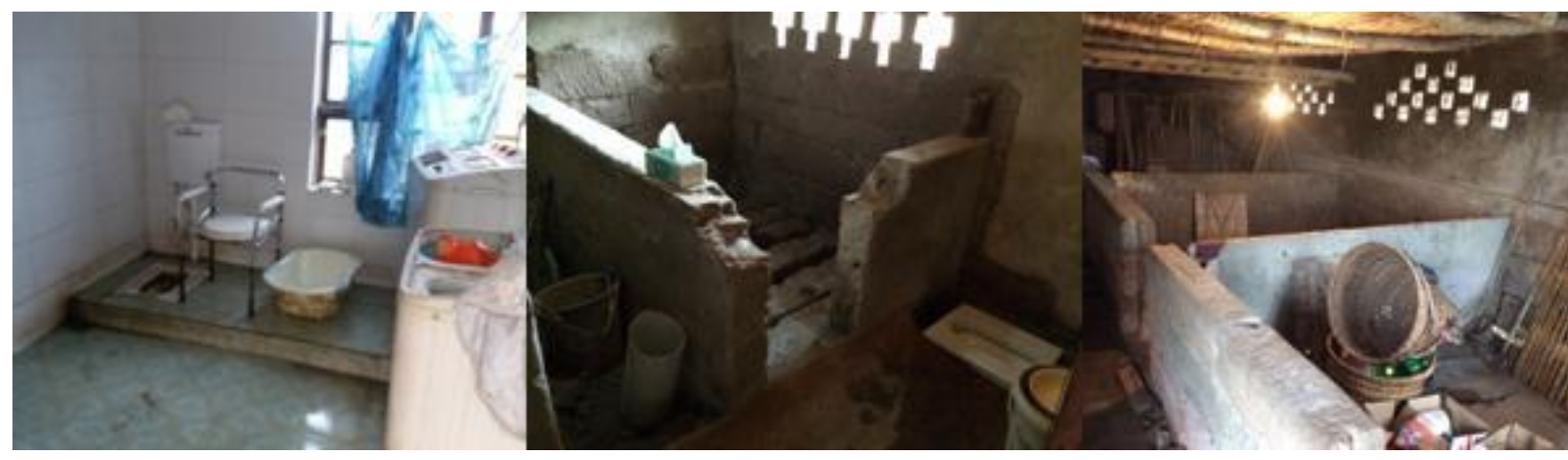

Figure 2. Pictures of rural latrines 
Table 3. Basic information of rural latrines

\begin{tabular}{|c|c|c|c|c|c|c|c|c|}
\hline \multicolumn{2}{|c|}{$\begin{array}{c}\text { Sanitation facilities } \\
\text { installation (number and } \\
\text { percentage) }\end{array}$} & Wall & Roof & Door & Closet & $\begin{array}{l}\text { Sanitary } \\
\text { fixture }\end{array}$ & $\begin{array}{c}\text { Fly } \\
\text { prevention } \\
\text { facility }\end{array}$ & $\begin{array}{c}\text { Decontamination } \\
\text { of feces }\end{array}$ \\
\hline \multirow{2}{*}{ Equipped } & Fully equipped & \multirow{2}{*}{$\begin{array}{c}144 \\
(94.1 \%)\end{array}$} & \multirow{2}{*}{$\begin{array}{c}145 \\
(94.8 \%)\end{array}$} & \multirow{2}{*}{$\begin{array}{c}132 \\
(86.3 \%)\end{array}$} & \multirow{2}{*}{$\begin{array}{c}57 \\
(37.3 \%)\end{array}$} & $\begin{array}{c}46 \\
(30.1 \%)\end{array}$ & \multirow{2}{*}{$30(19.6 \%)$} & \multirow{2}{*}{$60(39.2 \%)$} \\
\hline & $\begin{array}{c}\text { Incompletely } \\
\text { equipped }\end{array}$ & & & & & $\begin{array}{c}79 \\
(51.6 \%)\end{array}$ & & \\
\hline \multicolumn{2}{|c|}{ Unequipped } & $\begin{array}{c}9 \\
(5.9 \%)\end{array}$ & $\begin{array}{c}8 \\
(5.2 \%)\end{array}$ & $\begin{array}{c}21 \\
(13.7 \%)\end{array}$ & $\begin{array}{c}95 \\
(62.1 \%)\end{array}$ & $\begin{array}{c}28 \\
(18.3 \%)\end{array}$ & $123(80.4 \%)$ & $92(60.1 \%)$ \\
\hline \multicolumn{2}{|c|}{ Missing } & $0(0 \%)$ & $0(0 \%)$ & $0(0 \%)$ & $\begin{array}{c}1 \\
(0.7 \%)\end{array}$ & $0(0 \%)$ & $0(0 \%)$ & $1(0.7 \%)$ \\
\hline \multicolumn{2}{|r|}{ Total } & 153 & 153 & 153 & 153 & 153 & 153 & 153 \\
\hline
\end{tabular}

Regarding construction conditions, $94.1 \%$ of rural household latrines have walls; $94.8 \%$ of rural household latrines have a roof. $86.3 \%$ of rural household latrines have a door, $39.9 \%$ of tanks are not airtight, and only $58.2 \%$ of the tanks are airtight.

Regarding sanitary facilities of rural household latrines, $62.1 \%$ of rural household latrines have no toilets, and the missing rate is $0.7 \% .18 .3 \%$ of the household toilets do not have sanitary facilities such as storage bucket, special cleaning tools, paper containers, $51.6 \%$ of household latrines have parts of sanitary facilities, and $18.3 \% \%$ of household latrines do not have sanitary facilities. Only $19.6 \%$ of rural household latrines have fly prevention facilities. Basic information of rural latrines is shown in Table 3.

In the process of use, $36.6 \%$ of latrines' hygienic condition is good, $49.0 \%$ is moderate, and $14.4 \%$ is bad. Only $23.5 \%$ of the household toilets are basically free from bad odor, and $24.8 \%$ of the household latrines have detectable odor. Moreover, $16.3 \%$ of the failure frequency is under 3 months, $15.7 \%$ of the failure frequency is between 3-6 months, $15.7 \%$ of the failure frequency is between 6-12 months, $45.1 \%$ of the failure frequency is more than 12 months, and the missing percentage is $7.2 \%$.

$19.0 \%$ of the household latrine cost is under CNY500, $27.5 \%$ of the household latrine cost is between CNY500$1000,19.6 \%$ of the household latrine cost is between CNY1000-2000, $18.3 \%$ of the household latrine cost is over CNY2000, and the missing percentage is $15.7 \% .80 .4 \%$ of the funding resource rely on the residents their own, $5.2 \%$ of the funding resource is from government, $0.7 \%$ of the funding resource is from social capital, $6.5 \%$ of is depended on the collaboration of rural residents and government, $0.7 \%$ of is based on a combination of all financial sources, and the missing percentage is $6.5 \% .18 .3 \%$ of the construction of household latrines cause heavy economy burden to rural residents, $46.4 \%$ of the construction of household latrines cause moderate economy burden, $26.8 \%$ of the construction of household latrines cause little economy burden, and the missing percentage is $8.5 \%$.

As into village publicity and training, only $20.9 \%$ of interviewees indicated there were latrine related publicity and training in their villages, $74.5 \%$ of interviewees indicated no latrine related publicity and training in their villages, and the missing percentage is $4.6 \%$. Only $24.2 \%$ of interviewees chose there are unified plan for the household latrine in their villages, $71.2 \%$ of interviewees chose there are no unified plan for the household latrine in their villages, and the missing percentage is $4.6 \%$.

In the aspect of farmers' satisfaction, $72.5 \%$ of the rural residents are satisfied with the overall status of household latrines, and $27.5 \%$ of them were dissatisfied with the overall status of household latrines. $17.6 \%$ of rural residents believe that household toilet hygiene has no effect on the surrounding environmental hygiene, $46.4 \%$ of rural residents believe that household toilet hygiene has a certain effect on the surrounding environmental hygiene, $32.7 \%$ of rural residents believe that household toilet hygiene has great effect on the surrounding environmental hygiene, and the missing percentage is $3.3 \%$. $15.0 \%$ of rural residents believe that household toilet hygiene has no effect on the health of family and villagers, environmental hygiene, $43.8 \%$ of rural residents believe that household toilet hygiene has a certain effect on the health of family and villagers, environmental hygiene, $37.3 \%$ of rural residents believe that household toilet hygiene has great effect on the health of family and villagers, environmental hygiene, and the missing percentage is $3.9 \%$.

From the descriptive analysis we can see that the current rural latrine construction situation of Sichuan is not ideal. There are many problems, such as low percentage of feces decontamination, low percentage of sanitation facilities, bad conditions of sanitary and odor, and absence of village committee function. But, it is worth noting that even though the status quo of the construction of rural household toilets is not good, the satisfaction percentage of rural residents with household toilets is as high as $72.5 \%$.

\subsection{Factor Analysis}

\subsubsection{Missing Value Analysis}

SPSS software is used to analyze the data, and the missing value analysis is carried out first. The index of cost of household latrine has the biggest missing rate, which is 
$15.7 \%$, in addition, missing rates of subsidy percentage and village latrine related announcements and transparency reach $10.5 \%$ and $13.7 \%$ respectively. Meanwhile, the MCAR test significance $p=0.03$, so the hypothesis that the missing value is MACR is rejected. Therefore, EM method is used to run missing values. To ensure validity of the questionnaire after it was run, the validity and construct validity of the questionnaire were tested by the Cronbach's coefficient. The coefficient of the questionnaire data was 0.812 , indicating that the questionnaire is reliable.

\subsubsection{Factor Analysis}

The original data are normalized to eliminate the difference in magnitude and dimension. Factor analysis showed that the KMO statistic was 0.657 , and the $P$ value was 0.000 , hence the test results were significant. These data indicated that questionnaire data had a certain correlation, and it is suitable for factor analysis. Factor analysis showed that the extractions of 44 indicators are all above 0.5 , demonstrating that most of the information in the representation variable is extracted by factors. Using the principal component method to extract 15 factors, the researchers determined that their feature values are greater than 1 . The component matrix is rotated using the method of maximum variance orthogonal rotation because the initial loading structure is not clear. Moreover, loads of the indexes that whether the household latrine is $10 \mathrm{~cm}$ higher than terrace $(0.354)$ and whether the household latrine is reformed or not (0.377) are less than 0.4 on their common factors, and factor analysis is carried out again after deleting these two variables. Loads of the renovation reason $(0.384)$ is less than 0.4 on the common factor after the deletion of afore-mentioned indexes, so factor analysis is carried out again after the ren ovation reason is deleted. Similarly, in subsequent analysis, whether the household latrine is reformed or not, ventilation in the household latrine and repair approach, load of which are $0.361,0.304$ and 0.383 respectively, are deleted in proper order. Finally, indexes including whether the household latrine is $10 \mathrm{~cm}$ higher than terrace, whether the household latrine is reformed, renovation reason, ventilation in the household latrine and repair approach are deleted. Finally, we got 13 factors, and loads of indexes on their common factors are all above 0.4 after the component matrix is rotated, whereas the total variance explained is $69.4 \%$. The rotated component matrix is shown in Table 4 . We also can get the distribution of factor indices from Table 4 . The index situation and factor naming are shown in Table 5.

Table 4. Rotated Component Matrix

\begin{tabular}{|c|c|c|c|c|c|c|c|c|c|c|c|c|c|}
\hline \multirow{2}{*}{ Index } & \multicolumn{13}{|c|}{ Component } \\
\hline & 1 & 2 & 3 & 4 & 5 & 6 & 7 & 8 & 9 & 10 & 11 & 12 & 13 \\
\hline Gender $\left(\mathrm{X}_{2}\right)$ & .085 & .135 & -.183 & -.019 & -.084 & -.111 & -.073 & .040 & .020 & .093 & .122 & -.095 & .797 \\
\hline Age $\left(X_{3}\right)$ & .122 & -.267 & -.028 & .105 & -.105 & .045 & -.166 & -.355 & .564 & .189 & .043 & -.090 & .003 \\
\hline $\begin{array}{l}\text { Family members' highest } \\
\text { education level }\left(\mathrm{X}_{4}\right)\end{array}$ & -.011 & .085 & -.004 & -.100 & .014 & .050 & .061 & .195 & .829 & -.075 & .019 & .023 & -.022 \\
\hline Family annual income $\left(\mathrm{X}_{5}\right)$ & .066 & .050 & .163 & .048 & .134 & -.054 & .342 & .526 & .276 & -.094 & -.176 & .270 & .298 \\
\hline $\begin{array}{l}\text { Village housing distribution } \\
\left(\mathrm{X}_{6}\right)\end{array}$ & .130 & .130 & -.025 & .104 & .102 & -.206 & -.059 & .126 & .137 & .426 & .273 & -.082 & -.572 \\
\hline $\begin{array}{l}\text { Whether there is a household } \\
\text { latrine }\left(\mathrm{X}_{7}\right)\end{array}$ & .220 & -.095 & -.084 & .443 & .336 & .045 & -.024 & .013 & .062 & .162 & -.001 & .521 & -.052 \\
\hline Household latrine location $\left(\mathrm{X}_{8}\right)$ & .555 & .047 & .147 & .142 & .073 & .126 & .165 & -.080 & -.153 & -.371 & .073 & -.273 & -.034 \\
\hline Household latrine type $\left(\mathrm{X}_{9}\right)$ & .780 & -.041 & -.017 & .124 & -.027 & .024 & -.029 & .113 & .027 & .056 & -.057 & -.014 & -.031 \\
\hline $\begin{array}{l}\text { Household latrine use time } \\
\left(\mathrm{X}_{10}\right)\end{array}$ & .583 & .177 & .072 & .010 & .066 & .003 & -.084 & .073 & -.139 & .434 & .019 & .049 & .106 \\
\hline Household latrine area $\left(\mathrm{X}_{11}\right)$ & .145 & -.326 & -.030 & .031 & -.068 & .004 & -.022 & .557 & -.008 & .084 & .166 & -.281 & -.057 \\
\hline $\begin{array}{l}\text { The household latrine has walls } \\
\text { or not }\left(\mathrm{X}_{12}\right)\end{array}$ & .055 & .017 & -.183 & .759 & .084 & .088 & .069 & -.030 & -.121 & .034 & .119 & .127 & -.110 \\
\hline $\begin{array}{l}\text { The household latrine has a } \\
\text { roof or not }\left(\mathrm{X}_{13}\right)\end{array}$ & .048 & -.022 & .112 & .791 & .134 & -.165 & .113 & .115 & .011 & -.058 & .045 & -.047 & -.008 \\
\hline $\begin{array}{l}\text { The household latrine has a } \\
\text { door or not }\left(\mathrm{X}_{14}\right)\end{array}$ & .341 & -.209 & -.064 & .592 & -.244 & -.118 & .056 & .126 & .104 & -.120 & .041 & -.248 & .168 \\
\hline There is a closet or not $\left(X_{17}\right)$ & .664 & -.026 & -.060 & .145 & -.097 & .209 & -.074 & .137 & .044 & -.048 & -.177 & .158 & .064 \\
\hline
\end{tabular}




\begin{tabular}{|c|c|c|c|c|c|c|c|c|c|c|c|c|c|}
\hline $\begin{array}{l}\text { There is a decontamination of } \\
\text { feces or not }\left(\mathrm{X}_{18}\right)\end{array}$ & 187 & .076. & .068 & . 198. & .246 & .078 & .679 & .054 & .089 & .182 & -.049 & -.041 & -.125 \\
\hline $\begin{array}{l}\text { There are sanitary fixtures or } \\
\text { not }\left(\mathrm{X}_{19}\right)\end{array}$ & 720 & 139 & .027 & 102 & 086 & 128 & 248 & .007 & .121 & .163 & 026 & .035 & .123 \\
\hline $\begin{array}{l}\text { There is a fly prevention } \\
\text { facility or not }\left(\mathrm{X}_{20}\right)\end{array}$ & 34 & 078 & .280 & 037 & 200 & -.165 & 314 & 216 & .222 & .037 & 003 & .085 & .070 \\
\hline & 772 & 013 & -.077 & .026 & .079 & .065 & .263 & .003 & .086 & .072 & .175 & .016 & -128 \\
\hline $\begin{array}{l}\text { Frequency of feces cleaning } \\
\left(\mathrm{X}_{22}\right)\end{array}$ & 076 & 169 & .038 & 052 & -.206 & -.038 & .097 & .071 & -.053 & -.016 & .108 & .784 & -.041 \\
\hline $\begin{array}{l}\text { Whether the tank is airtight } \\
\text { without leakage }\left(\mathrm{X}_{23}\right)\end{array}$ & 211 & 048 & 090 & .060 & .194 & .001 & .721 & .013 & -.102 & .035 & .088 & .098 & .029 \\
\hline & 756 & .060 & 048 & -.076 & 157 & .035 & .093 & .108 & .057 & .078 & .068 & .044 & .039 \\
\hline Cost $\mathrm{o}$ & .201 & .182 & 055 & .129 & & .146 & 56 & .733 & .037 & 40 & .063 & -.008 & -.036 \\
\hline & 073 & .744 & 120 & -.075 & -.013 & .313 & .120 & .094 & -.060 & -.024 & -.027 & .035 & -.020 \\
\hline & 05 & .551 & 019 & .083 & .230 & .269 & .040 & -.033 & .338 & .157 & -.118 & -.170 & -.105 \\
\hline $\begin{array}{l}\text { Management and maintena } \\
\text { participants of household }\end{array}$ & 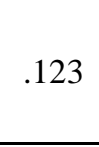 & .15 & .007 & 054 & .073 & t & .226 & -.083 & .004 & .693 & -.103 & .013 & .010 \\
\hline in & & .80 & .014 & 051 & 0 & .099 & 091 & -.040 & .201 & .114 & .162 & & .068 \\
\hline $\begin{array}{l}\text { Pay } \\
\left(\mathrm{X}_{3}\right. \\
\end{array}$ & 066 & .716 & 027 & 032 & 163 & 005 & 147 & .033 & 194 & .177 & -.127 & -.162 & .105 \\
\hline & & & & & & & & & & & & & .010 \\
\hline $\begin{array}{l}\text { Fina } \\
\text { hous }\end{array}$ & 074 & -.147 & .042 & .154 & 729 & -.046 & .017 & .009 & .030 & .207 & -.045 & -.020 & .027 \\
\hline & 24 & .010 & 166 & .001 & 726 & -.178 & -.002 & -.104 & -.055 & -.149 & .157 & -.114 & -.160 \\
\hline Failure recovery time $\left(\mathrm{X}_{37}\right)$ & & $\cdot$ & -.220 & .0 & .2 & .206 & -.048 & -.087 & -.043 & .1 & 4 & .059 & .299 \\
\hline $\begin{array}{l}\text { W } \\
\text { re } \\
\text { lat }\end{array}$ & 049 & -.037 & .152 & .176 & .040 & -.027 & .027 & .098 & .007 & -.157 & .808 & .093 & -.041 \\
\hline & 23 & .175 & .235 & .026 & 013 & .231 & .079 & .045 & .089 & .144 & .459 & 29 & .169 \\
\hline $\begin{array}{l}\text { Availability of publicity and } \\
\text { training in the construction, } \\
\text { renovation, use and } \\
\text { management of rural latrine in }\end{array}$ & .160 & .142 & .208 & -.076 & -.077 & .817 & -.051 & .024 & .082 & -.093 & .064 & -.102 & -.027 \\
\hline $\begin{array}{l}\text { Does the village have a unified } \\
\text { plan for the household latrine? } \\
\left(\mathrm{X}_{41}\right)\end{array}$ & 01 & .242 & .184 & -.065 & -.172 & .696 & 32 & .133 & .015 & .199 & .004 & .095 & -.006 \\
\hline $\begin{array}{l}\text { Influence on surrounding } \\
\text { sanitation of household latrine }\end{array}$ & -.010 & -.065 & .871 & -.012 & -.011 & .214 & -.118 & -.012 & -.054 & .038 & .160 & -.033 & -.081 \\
\hline $\begin{array}{l}\text { Influence on health of family } \\
\text { and villagers of household } \\
\text { latrine }\left(\mathrm{X}_{43}\right)\end{array}$ & 17 & .020 & .905 & 078 & -.077 & .097 & -.012 & -.008 & .023 & -.033 & .018 & .038 & -.084 \\
\hline
\end{tabular}


Table 5. Indicators in Each Factor

\begin{tabular}{ll}
\hline \multicolumn{1}{c}{ Factor } & \multicolumn{1}{c}{ Index } \\
\hline$F_{1}$ (Basic conditions of rural latrines) & $X_{8}, X_{9}, X_{10}, X_{17}, X_{19}, X_{20}, X_{21}, X_{24}$ \\
\hline$F_{2}$ (Fund \& construction participants and pattern) & $X_{28}, X_{29}, X_{31}, X_{32}, X_{33}$ \\
\hline$F_{3}$ (Rural residents' cognition) & $X_{42}, X_{43}$ \\
\hline$F_{4}$ (Building condition) & $X_{12}, X_{13}, X_{14}$ \\
\hline$F_{5}$ (Economic burden \& failure frequency) & $X_{34}, X_{35}$ \\
\hline$F_{6}$ (Village committee performance) & $X_{40}, X_{41}$ \\
\hline$F_{7}$ (Decontamination of feces \& Tank air tightness) & $X_{18}, X_{23}$ \\
\hline$F_{8}$ (Family annual income \& cost \& area) & $X_{5}, X_{11}, X_{26}$ \\
\hline$F_{9}$ (Age \& family members' highest education level) & $X_{3}, X_{4}$ \\
\hline$F_{10}$ (Management maintenance participants) & $X_{30}$ \\
\hline$F_{11}$ (Recovery time \& worth \& transparency of village affairs) & $X_{37}, X_{38}, X_{39}$ \\
\hline$F_{12}$ (whether there is household latrine \& frequency of sludge cleaning) & $X_{7}, X_{22}$ \\
\hline$F_{13}$ (Gender \& village housing distribution) & $X_{2}, X_{6}$ \\
\hline
\end{tabular}

\subsection{Logistic Regression Analysis Based on Factor Analysis}

The dependent variable of this paper is the total satisfaction of rural households with household latrines, which is divided into two categories: "satisfied" and "dissatisfied". Logistic regression analysis was used to analyze 13 factors. The results of the omnibus test are shown in Table 6, and the results of Hosmer and Lemeshow test are shown in Table 7.

Table 6. Omnibus Test of Model Coefficients

\begin{tabular}{ccccc}
\hline & & $\begin{array}{c}\text { Chi- } \\
\text { square }\end{array}$ & df & Significance \\
\hline Step 1 & Step & 58.358 & 13 & 0.000 \\
\hline & Block & 58.358 & 13 & 0.000 \\
\hline Model & 58.358 & 13 & 0.000 \\
\hline
\end{tabular}

Table 7. Hosmer and Lemeshow Test

\begin{tabular}{cccc}
\hline Step & Chi-square & df & Significance \\
\hline 1 & 4.628 & 8 & 0.796 \\
\hline
\end{tabular}

Table 7 shows that the Chi-square is 4.628 , indicating that there is no significant difference between the actual value of the variable and the predicted value. The significance $(P)$ value is 0.796 , showing that the assumption of the model fits the data well cannot be rejected, which means that the model fits the data well. The model has a $-2 \mathrm{Ln}$ likelihood of 121.476, and the prediction accuracy of the model reached $77.8 \%$. Wang (2008) has summed up the domestic and he found that the correctly classify percentages of these papers are among $54 \%$ to $90 \%$. Correctly classify percentages in papers of Tang et al (2010), $\mathrm{Li}$ (2008) and Langer et al (2018) are from $66.8 \%$ to $83.7 \%$. Hence the correctly classify rate in this paper is within the acceptable range. Estimation results of the model are shown in Table 8 .

Table 8. Model Estimation Results

\begin{tabular}{ccc}
\hline Variable & $\begin{array}{c}\text { Parameter Value } \\
\text { and Significant } \\
\text { Level }\end{array}$ & Wald \\
\hline $\mathrm{Ln}\left(\mathrm{F}_{1}\right)$ & $1.237^{* * *}$ & 17.915 \\
\hline $\mathrm{Ln}\left(\mathrm{F}_{2}\right)$ & $1.078^{* * *}$ & 6.928 \\
\hline $\mathrm{Ln}\left(\mathrm{F}_{3}\right)$ & -0.109 & 0.208 \\
\hline $\mathrm{Ln}\left(\mathrm{F}_{4}\right)$ & 0.369 & 2.284 \\
\hline $\mathrm{Ln}\left(\mathrm{F}_{5}\right)$ & $0.410^{*}$ & 3.094 \\
\hline $\mathrm{Ln}\left(\mathrm{F}_{6}\right)$ & $0.993^{* * *}$ & 10.296 \\
\hline $\mathrm{Ln}\left(\mathrm{F}_{7}\right)$ & 0.044 & 0.037 \\
\hline $\mathrm{Ln}\left(\mathrm{F}_{8}\right)$ & 0.203 & 0.643 \\
\hline $\mathrm{Ln}\left(\mathrm{F}_{9}\right)$ & -0.383 & 2.133 \\
\hline $\operatorname{Ln}\left(\mathrm{F}_{10}\right)$ & $0.592^{* *}$ & 4.495 \\
\hline $\operatorname{Ln}\left(\mathrm{F}_{11}\right)$ & $0.720^{* * *}$ & 9.037 \\
\hline $\operatorname{Ln}\left(\mathrm{F}_{12}\right)$ & 0.050 & 0.050 \\
\hline $\operatorname{Ln}\left(\mathrm{F}_{13}\right)$ & 0.268 & 1.388 \\
\hline $\operatorname{constant}$ & 1.667 & 28.034 \\
\hline
\end{tabular}

Note: ${ }^{*},{ }^{*},{ }^{* * *}$ represent the significant level of $10 \%, 5 \%$ and $1 \%$, respectively. 
The Wald test is used to test the significance of Logistic regression, and it is a common test method of statistical software to test significance of Logistic regression. Under the zero hypothesis, each regression coefficient is equal to 0 , then the univariate Wald statistic is a gradual $\chi^{2}$ distribution with the degree of freedom equal to 1 . Therefore, the significance of corresponding model independent variables can be determined according to whether the value of the Wald statistic is greater than the critical value of the $\chi^{2}$ under the degree of freedom equal to 1 (Wang and Guo 2001).

\subsection{Discussion}

According to the Wald value in Table 8, factors with significant effect on the satisfaction of farmers include $F_{1}, F_{6}$, $F_{11}, F_{2}, F_{10}$, and $F_{5}$, and their effect size is decreased in turn.

$F_{1}$ represents the basic conditions of rural latrines, which reflects mainly the location, type, facilities and sanitation condition of rural household latrines, with a significant level of $1 \%$. It has a very significant positive effect on rural residents' satisfaction in all factors. Specifically, the better the basic conditions of rural latrines, the higher the overall satisfaction.

$\mathrm{F}_{6}$ represents the village committee performance factor, which includes village publicity and training and village unified plan, with a significance level of $1 \%$. It has a positive effect on rural residents' satisfaction, meaning the more publicity and training are provided to rural residents and the better unified plan in village, the more the rural residents are satisfied with their household latrines.

$\mathrm{F}_{11}$ represents recovery time \& worth \& transparency of village affairs. It has a significance of $1 \%$ and has a positive effect on rural infrastructure satisfaction. Household toilets failure recovery after damage faster, the villagers think that it is more worth of household toilet building cost. The more transparent the village work is, the more the rural residents are satisfied.

$\mathrm{F}_{2}$ represents fund and construction participants and pattern, which has a significance of $1 \%$. It includes building/renovation pattern, building/renovation participants, funding sources, subsidies etc. $F_{2}$ has a positive effect on rural infrastructure satisfaction, indicating that the more government guides, the more outside help, the more funds and subsidy funds, the faster the subsidy funds arrive, and the more the rural residents are satisfied.

$\mathrm{F}_{10}$ represents management maintenance participants, which has a significance of $5 \%$ and has a certain positive effect on rural residents' satisfaction. It shows that the more professional maintenance the rural household toilets get in the process of using, the more the rural residents are satisfied.

$\mathrm{F}_{5}$ represents economic burden \& failure frequency, which has a significance of $5 \%$ and has a certain positive effect on rural residents' satisfaction. The smaller the economic burden of construction and reconstruction is, the lower the frequency of rural household toilet failure, and the more the rural households are satisfied.

The top four factors that affect farmers' satisfaction are "basic conditions of rural latrines", "village committee performance", "recovery time $\&$ worth $\&$ transparency of village affairs" and "fund $\&$ construction participants". The basic condition of rural latrines influences rural residents' satisfaction most significantly. It shows that convenience, comfort and hygiene could affect users' feeling directly in the use of toilets. Tang et al (2003) pointed that there were $40.7 \%$ of household latrines indoor, $14.1 \%$ of household latrines had closet, and $38.9 \%$ of household latrines have bad smell. In this survey, $51.6 \%$ of the household latrines are located indoor, $30 \%$ of the latrines are pit or loop style, $30.1 \%$ of household latrines have equipped facilities, $24.8 \%$ of latrines have smell. It shows that the situation of rural latrines in Sichuan has got better, but it is still not optimistic. It still needs to increase the intensity of latrine construction to improve the basic conditions of rural household latrines.

Liu et al (2016) summarized the successful experience of Shijiazhuang as well publicity, good technical guide, fund guarantee etc. Only $20.9 \%$ of interviewees chose the option that their villages have latrines related training and publicity, and only $25.3 \%$ of interviewees chose the option that their villages have unified plan for their household latrines. On the other hand, the significant influence of village committees' performance on rural residents' satisfaction also shows rural residents' expectation for government guidance.

The survey results show that $55.6 \%$ of rural latrines' failure could get recovered within $12 \mathrm{~h}$, and the failure recovery time of $19.3 \%$ household toilet is more than 24 hours. A long failure recovery time would seriously affect the normal use of latrines in rural areas. $87.6 \%$ of rural residents think that the construction and reform of the household latrine is worth, indicating that they have realized the importance of rural household latrine. Only $24.2 \%$ of the rural residents think that the related affairs of the household toilet construction in the village were informed well. The higher transparency of village affairs can help rural residents understand work arrangements and policy conditions of the government, and help them make full use of social and government resources in household latrine construction work, therefore to improve household latrine construction quality and cost savings.

The funds of rural household toilet reform directly affect the construction quality of rural household latrine. Multiple sources of funding can ensure rural household latrine construction work go on wheels, and it could help to improve the level and quality of the rural household latrines construction. It will increase the economic burden of village committee and may even cause a stoppage during the latrine reform (Hang 2008). In view of the fact that many village economies are relatively weak and rural household latrines work is an important part of building a new socialist countryside, all levels of financial subsidies should increase investment to help the rural household latrines reform. On the other hand, the collaboration between government and social enterprises not only could arouse the enthusiasm of rural residents, but also provide professional technical guidance for the construction and renovation of rural household latrines. Hang (2008), Hou and Wang (2011) have pointed out that there are such problems as non-standard operation of construction team, lack of technical guidance, and the delayed payment of subsidy funds in the reform of rural household toilets in China. They also proposed 
suggestions to strengthen government attention, strengthening technical guidance and timely subsidy funds. Problems in above studies coincide with this article.

It is worth noting that, although the survey results show that the construction of rural household toilets is not good and there are still many aspects need to be improved, the satisfaction rate of rural residents is respectively high. This reflects that rural residents do not have enough understanding for rural household latrines and have low expectation for household toilets. The government still needs more publicity to help rural residents understand the importance of sanitary latrine and its impact on public health, therefore to stimulate rural residents' enthusiasm for sanitary latrines improvement.

\section{Conclusion}

This paper conducted an investigation of the situation of rural household latrines from the perspective of farmers' satisfaction. Factor analysis and logistic regression model were used to analyze rural household latrines' situation and rural residents' attitudes. The condition of rural household latrines and rural residents' attitudes are analyzed from aspects of building condition, cost, using condition and rural residents' cognition. The results show that the rural residents' satisfaction rate of rural household latrines is $72.5 \%$, and their demand for rural household toilet is basically satisfied. On the other hand, the construction of rural household toilet is not ideal. The analysis results show that rural residents' satisfaction of rural household latrine is mainly affected by "basic situation of latrines", "village committee performance", "recovery time \& worth \& transparency of village affairs" and "fund \& construction participants".

From the results, we can see that there are still some problems existing in the construction of rural household toilets, such as unsatisfactory status of household toilet construction, absence of government functions and insufficient understanding of rural residents' situations. In order to better promote the construction of rural household latrine in Sichuan, the government should play a better role in their functions, increase publicity, make good planning, improve the farmers' understanding of rural household toilets, which in turn, will change the rural household latrine construction situation, and to create a better environment for the health of rural residents.

This paper studies the present situation of the construction of rural household latrines in Sichuan and discusses rural residents' attitudes toward rural household latrines. It lays a foundation for further research on the development of rural household latrines construction and provides a theoretical basis for policy makers. Indexes in this research are derived from previous studies, most of which are aimed at other provinces. Therefore, these indexes may not reflect the rural household latrines situation of Sichuan. It is hoped that indexes could get further adjustment after this research, so that a comprehensive index system could be established to study the current situation of rural household latrines construction in Sichuan. At the same time, this paper uses questionnaire survey, which did not get rural residents' opinions completely. So the semi-structured method could be used in investigations to get a more comprehensive understanding of rural residents' attitude for rural household latrine construction.

\section{Data Availability}

The data used in this manuscript is from the field survey between March to April 2017. Readers can get it from anyone of the authors.

\section{Acknowledgement}

The Natural Science Key Project from Sichuan Provincial Department of Education (18ZA0048) the Fundamental Philosophy and Social Science Research Fund for Chengdu University of Technology (YJ2017-NS011). The Research on BIM Technology Resource Sharing Platform Construction and Cooperation Mechanism (CHJK $\{2017\}$ 119). Development Research Center of Oil and Gas, Sichuan (CYQK-SKB17-04).

\section{References}

Anagnostopoulos, K. and A. Vavatsikos, 2012. Site suitability analysis for natural systems for wastewater treatment with spatial fuzzy analytic hierarchy process. Water Resources Planning and Management, 138(2): 125 - 134.

Ao, Y.B., J.Y. Li, Y. Wang, C.J. Liu and S.H. Xu, 2017. Famers' satisfaction of rural facilities and its influencing indicators: a case study of Sichuan, China. Mathematical Problems in Engineering, 11: 1 - 12. doi: 10.1155/2017/1908520.

Back, J.O., M.O. Rivett, L.B. Hinz, N. Mackay, G.J. Wanangwa, O.L. Phiri, C.E. Songola, M.A.S. Thomas, S. Kumwenda, M. Nhlema, A.V.M. Miller and R.M. Kalin, 2018. Risk assessment to groundwater of pit latrine rural sanitation policy in developing country settings. Science of the Total Environment, 613-614: 592 - 610. doi: 10.1016/j.scitotenv.2017.09.071.

Beukes, L.S., T.L.B. King and S. Schmidt, 2017. Assessment of pit latrines in a peri-urban community in KwaZuluNatal (South Africa) as a source of antibiotic resistant $E$. coli strains. International Journal of Hygiene and Environmental Health, 220: 1279 - 1284.

Ferrante, M., S.S. Signorelli, S.L. Ferlito, A. Grasso, A. Dimartino and C. Copat, 2018. Groundwater-based water wells characterization from Guinea Bissau (Western Africa): a risk evaluation for the local population. Science of the Total Environment, 619-620: 916 - 926.

Fu, F.Y., W. Yao, B.H. Liu, M.K. You, X.G. Qu and J.Y. Yao, 2004. Investigation on improvement of rural toilets in five Provinces in China. Hygiene Research. 34(4): 219 220.

Fu, Y.F., H.Y. Ji, C. Neil, Z.S. Wang and Y. Tao, 2006. Status quo of rural toilets in 5 Counties of Xianyang. Public Health, 22(7): 881 .

Gedefaw, M., Y. Amsalu, M. Tarekegn and W. Awoke. 2015. Opportunities and challenges of latrine utilization among 
rural communities of Awabel District, Northwest Ethiopia, 2014. Open Journal of Epidemiology, 5: 98 106.

Glick, S., A.A. Guggemos and A.M. Asce 2013. Rethinking wastewater-treatment infrastructure: case study using life-cycle cost and life-cycle assessment to highlight sustainability considerations. Construction Engineering and Management, 139(12): A5013002

Guo, X.W., L.Z. Xu and L.Y. Zhou, 2008. Investigation on sanitary latrines in rural areas of Liaocheng City in 2008. Prev Med Trib, 16(16): 129 - 130.

Hang, B., 2008. Difficulties and countermeasures of latrines reform in rural areas. Chinese Primary Health Care, 22 (3): 68 - 79 .

Hiscox, A.H.R., K. Vongphayloth, N. Hill, S.W. Lindsay, M. Grandadam and P.T. Brey., 2016. Armigeres subalbatus colonization of damaged pit latrines: a nuisance and potential health risk to residents of resettlement villages in Laos. Medical and Veterinary Entomology, 30: 95 100.

Hou, K.N. and W.D. Wang, 2011. Study on rural toilet transformation under the background of rural civilization construction. Hebei Agricultural Sciences, 15(8): 98 100.

Hussain, F,T. Clasen, S. Akter, V. Bawel, S.P. Luby, E. Leontsini, L. Unicomb, M. K. Barua, B. Thomas and P. J. Winch, 2017. Advantages and limitations for users of double pit pour-flush latrines: a qualitative study in rural Bangladesh. BMC Public Health, 17: 515 - 524.

Hygienic specification for rural household latrine (GB19379 -2012). 2012. People's Republic of China state health and Family Planning Commission.

Jin, L.J., C.Z. Cao and H.X. Huang, 2007. Current condition of latrine improvement project in rural area of Sichuan Province. J Prev Med Inf, 23(4): 430 - 432.

Kumwenda, S., C. Msefula, W. Kadewa, Y. Diness, C. Kato, T. Morse and B. Ngwira, 2017. Is there a difference in prevalence of helminths between households using ecological sanitation and those using traditional pit latrines? A latrine based cross sectional comparative study in Malawi. BMC Res Notes, 10: 200 - 208.

Langer, K., T. Decker, J. Roosen and K. Menrad, 2018. Factors influencing citizens' acceptance and nonacceptance of wind energy in Germany. Cleaner Production, 175: 133 - 144.

Li, W.D., 2008. Application of Multivariate Statistical Analysis. Beijing: Peking University Press

Li, Z.C., J. Chen, H.L. Du, B. Liu, K. Huang and X.F. Gao, 2013. Analysis on influence factors of hazard - free effects of improved latrines in rural areas in Chengdu. Med Pest Control, 29(3): 247 - 250.

Liang, S.H., Y. Zhang and H.J. Jiang, 2002. Effect of rebuilding sanitary latrines on environmental sanitation quality in rural areas of Tongbai County. Henan J Prev Med, 13(2): 104 - 105.

Lin, Z.S., G.Z. Chen, J.W. Guo, S.R. Lai, X.M. Chen, L.P. Chen and C.Y. Lu, 2008. Investigation and analysis of rural toilet in Fujian. Prev Med, 9(7): 645 - 647.

Liu, G.P., L.F. Wang and Y.F. Hou, 2016. Practice and experience of rural toilet reform in Shijiazhuang. J Med Pest Control, 32(3): 348 - 351.

Niu, L.J. and G.H. Zu, 2004. Research report of rural latrines related behavior influence factor. Chinese Rural Health Management, 24(6): 20 - 23.

Olchmaher, C.G. and C.J. Davis, 2003. Using multiple regression and GIS technology to predict landslide hazard in northeast Kansas, USA. Engineering Geology, 69: 331 - 343.

Pan, S.C., G.H. Xu, Y.Z. Wu, J.H. Li, et al, 1995. A background survey and future strategies of latrines and night soil treatment in rural in China. Hygiene Research, 24: 1 - 10.

Peng, D.Y., 2012. Performance Evaluation of Rural Public Investment Based on Farmers' Satisfaction. Shandong: Shandong Agricultural University.

Sichuan Statistics Yearbook, 2017. Statistical Bureau of Sichuan.

Tang, D.J., J.P. Xian and S. Wen, 2003. Investigation of rural toilet situation in Cangxi County and Mabian County, Sichuan. Chinese Journal of Health Education, 19(1): 49 $-50$.

Tang, J.L., Y.C. Zhu and C.M. Liu, 2010. Analysis of rural public service satisfaction and its influencing factors -based on the survey of 67 villages in 32 towns in Shaanxi Province. Contemporary Economic Science, 32(1): 101 116.

Wang, L., 2008. The study of SMEs Credit Scoring based on Logistic Regression Model. Hefei University of Technology.

Wang, J.C. and Z.G. Guo, 2001. Logistic Regression Models: Methods and Application.in Beijing. Higher Education Press.

Wen, Z.K., Y. Yang and C.Y. Wu, 2005. Economic and social benefit analysis of improvement of latrines in countryside of Hunan Province, China. Environ Health, 22(6): 445 - 447.

$\mathrm{Wu}, \mathrm{G} ., 2003$. Main problems and countermeasures of latrines reform in rural areas. Chinese Primary Health Care, 17(8): 75 - 76.

Yang, C., L. Song and J. Jing, 2005. Status and suggestions of toilet reform in rural areas. Chinese Journal of Public Health Engineering, 4(4): 229 - 231.

Yao, W., X.G. Qu, H.X. Li and Y.Y. Fu, 2009. Present situation of rural toilets and excreta utilization in China. Environ Health, 26(1): 12 - 14.

Ye, X.G. and D. An, 2013. Review of the construction of rural sanitary toilet. Chin J of Public Health Eng, 12(1): $79-81$.

Yishay, A.B., A. Fraker, R. Guiteras, G. Palloni, N.B. Shah, S. Shirrell and P. Wang, 2017. Microcredit and willingness to pay for environmental quality: evidence from randomized-controlled trial off finance for sanitation in rural Cambodia. Environmental Economics and Management, 86: 121 - 140.

Zhan, X.H., L.P. Chen and Z.S. Lin, 2011. A preliminary study on rural latrine reform and basic economic situation in Fujian during the past 2005-2009. Chinese Primary Health Care, 25(4): 96 - 97. 
Zhang, C.Y., C. Mei and L. Ying, 2005a. The situation and main problems of rebuilding sanitary toilets in rural areas of Sichuan. Modern Preventive Medicine, 32(2): 153 154.

Zhang, C.J., Y.Q. Lu and H.Y. Zhao, 2008. Cultural analysis of barriers to toilet improvement in rural areas. Chin. J of PHM, 24(1): 2.

Zhang, C.Y., Q. Ling, L.J. Jin, H.C. Tang, D.J. Tang and H.X. Huang, 2013. Lavatory reformation project in rural areas of Sichuan. J Prev Med Inf, 29(6): 450 - 453.

Zhang, K.W., S.Y. Zhang and R.S. Yang, 2000. Crosssectional investigation on household latrines and excreta treatment in countryside of Shandong Province.
Environment and Health, 17(6): 327 - 328.

Zhang, J., 2012. Investigation and analysis of the status quo of rural public toilet in Tianjin. Environment Sanitation Engineering, 20(4): 25 - 27.

Zhang, Y.Q., W.T. Bi and Y. Yang, 2005b. Investigation and analysis of the influence of rural latrine reform on farmers' health awareness and behavior. Chinese Journal of Health Supervision, 12(2): 92 - 95.

Zhou, J. and Y.J. Liu, 2015. The method and index of sustainability assessment of infrastructure projects based on system dynamics in China. Industrial Engineering and Management, 8(3): 1002 - 101. 